Gut, 1986, 27, S1, 85-95

\title{
Nutritional support: how much for how much?
}

\author{
R L KORETZ \\ Division of Gastroenterology, Olive View Medical Center, Sylmar, California, USA
}

SUMMARY Although malnutrition is associated with poor clinical outcome, it cannot be inferred that better nutrition will improve clinical outcome. Efficacy of a proposed regimen is best established by prospective, randomised, controlled trials. Cost effectiveness is only an issue if efficacy exists. Patients with long term temporary, or permanent, inadequate bowel syndrome are candidates for parenteral nutrition. Most of the prospective, randomised, controlled trials testing the value of nutritional support in other diseases, however, have failed to show that this treatment has a beneficial clinical effect. Areas where these trials have shown a possible clinical benefit include the perioperative care of patients with upper gastrointestinal cancer, elemental diet treatment of Crohn's disease, and branched chain amino acid infusions in hepatic encephalopathy. Even in these instances, it is not clear that such treatment will prove to be cost effective (compared with other currently available treatments).

About 50 years ago Studley observed that patients who had lost more than $20 \%$ of their weight had an eight-fold higher surgical mortality compared with those who had lost less. ${ }^{1}$ The association between poor nutritional variables and poor clinical outcome has been one of the bases for the growth of therapeutic nutritional support, now a multibillion dollar a year endeavour. Association, however, does not prove causation; a poorer nutritional state may be a consequence of a more severe underlying disease. Therapeutic efficacy is traditionally established by prospective, randomised, controlled trials. This paper will review the prospective randomised controlled trials of nutritional support, identify areas where efficacy is or may be established, and consider the cost of nutritional support in those areas.

All of the reviewed trials measured clinical outcome criteria such as morbidity, mortality, or duration of hospital stay. Studies on nutritional criteria only such as nitrogen balance or serum albumin will not be discussed. In the studies of parenteral nutritional support at least one group received intravenous nitrogen (hydrolysates or amino acids) with or without high calorie loads and a control group did not receive nitrogen parenterally. In the trials of enteral nutritional support an organised effort was made to provide enteral feeding

Correspondence to: Dr R L Koretz, Department of Medicine. Olive View Medical Center, 14445 Olive View Medical Drive, Sylmar. California 91342. USA. (usually liquid diets) to one (or more) group(s) but not to the control group. At the time of writing, 64 parenteral and 29 enteral trials have been identified. In the following discussion, unless otherwise indicated, differences in outcome between the study and control groups will only be noted if they are significant $(p<0.05)$.

\section{Cancer}

Patients with cancer are often malnourished: chemotherapy or radiation treatment exacerbate this problem. Nutritional support might be expected to benefit this group of patients. Unfortunately, few positive effects of nutritional support in "oncotherapy" have been shown.

The role of parenteral nutrition as an adjunct to treatment has been evaluated in 17 trials. ${ }^{2-22}$ None of these studies has shown any favourable effect of parenteral nutrition on survival; patients with colorectal cancer receiving parenteral nutrition had a significantly worse survival ( 79 days) compared with that of the control group (308 days). ${ }^{4}$ Haematological variables were favourably influenced in two studies, ${ }^{8} 17$ but in three other trials ${ }^{11}{ }^{13} 20$ those receiving parenteral nutrition had a poorer outcome. Gastrointestinal side effects were improved in two ${ }^{5}$ but worse in two others. ${ }^{40}$ All seven

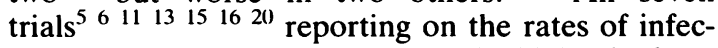
tious complications found them to be higher in those receiving parenteral nutrition; in four ${ }^{5} 131520$ the 
differences were significant. There was an increased incidence of bleeding in children treated with radiation and parenteral nutrition. ${ }^{19}$

Terminal patients receiving only parenteral nutrition - that is, no specific treatment for cancer - lived 46 days, compared with seven days in the control group. ${ }^{17}$ This observation has no important clinical application.

Enteral nutrition has also not had an important effect in this area. Only one $e^{23}$ of five $e^{23-27}$ trials evaluating elemental diets had any remotely favourable effect at all, a reduction in diarrhoea in patients undergoing radiation $(0 \cdot 10>p>0 \cdot 05)$. Another four trials found liquid feeding ${ }^{28-30}$ or intact foodstuffs (D Nixon, personal communication) to be of little benefit; in one $e^{28}$ of these trials, there was less neutropenia in those receiving enteral nutrition.

\section{Perioperative nutritional support}

Four trials have evaluated the use of the peripheral infusions of amino acids during the perioperative period (J Daly, personal communication). ${ }^{31-33}$ None showed any effect of this treatment on the morbidity or mortality of the surgical patients. Four other trials found that parenteral nutrition did not affect patients undergoing cardiac, otolaryngological, urological, or vascular procedures. ${ }^{3+37}$

Three studies of parenteral nutrition were directed at patients who had undergone colorectal surgery. ${ }^{38-40}$ Although the perioperative mortality was uninfluenced, in two ${ }^{38-40}$ the duration of hospital stay was at least arithmetically shorter for those receiving parenteral nutrition (by four to six days). There was a reported "significant less" postoperative complication rate in the parenteral nutrition recipients in one of these trials, ${ }^{40}$ but the specific numbers are unavailable. In the third trial ${ }^{30}$ the use of parenteral nutrition was associated with an increase in radiologically confirmed anastomotic leaks. These data are too preliminary to conclude whether or not parenteral nutrition is beneficial when used in patients who have undergone colorectal surgery.

Three centres assessed the value of parenteral nutrition in patients undergoing surgery for various gastrointestinal malignancies ${ }^{4-43}$; two found no effect whatsoever. ${ }^{41}{ }^{42}$ The West German study ${ }^{43}$ is, perhaps, the most often cited study supporting the use of parenteral nutrition. Muller et al found reductions in postoperative mortality $(19 \% \vee 5 \%)$ and major morbidity $(22 \% \vee 11 \%)$ associated with parenteral nutrition. Not mentioned in the paper, however, was a second treatment group, receiving a different parenteral formulation, which was dropped from the study before its completion (J Muller, personal communication). Furthermore, the patients were stratified according to tumour site, and the differences were only present in those with gastric and oesophageal malignancies. ${ }^{44}$ The major cause of mortality and morbidity in this second group was anastomic leakage, which essentially disappeared in both groups when an anastomotic stapler was used (J Muller, personal communication).

Table 1 gives details of the patients with upper gastrointestinal malignancies participating in the remaining perioperative parenteral nutrition trials. ${ }^{45-51}$ Only the differences between the incidence of wound infections seen in the Cardiff study were significant. ${ }^{45}$ In five of seven studies, however, the mortality was better in the recipients of parenteral

Table 1 Perioperative parenteral nutrition in upper gastrointestinal cancer surgery

\begin{tabular}{|c|c|c|c|c|}
\hline $\begin{array}{l}\text { Refer- } \\
\text { ence }\end{array}$ & Treatment & $(n=)$ & $\begin{array}{l}\text { Survival } \\
(\%)\end{array}$ & $\begin{array}{l}\text { Complications } \\
(\%)\end{array}$ \\
\hline 45 & $\begin{array}{l}\text { Parenteral } \\
\text { nutritional sup- } \\
\text { port } 5-7 / 6-7 \\
\text { Control }\end{array}$ & $\begin{array}{l}(38) \\
(36)\end{array}$ & $\begin{array}{l}32(84) \\
28(78)\end{array}$ & $\begin{array}{l}14^{*}(40) \\
30^{*}(83)^{* *}\end{array}$ \\
\hline 46 & $\begin{array}{l}\text { Parenteral } \\
\text { nutritional sup- } \\
\text { port } 28 / 0 \\
\text { Enteral } 28 / 0\end{array}$ & $\begin{array}{l}(12) \\
(12)\end{array}$ & $\begin{array}{l}11(91) \\
10(83)\end{array}$ & $\begin{array}{c}6^{*}(50) \\
12^{*}(100)\end{array}$ \\
\hline 47 & $\begin{array}{l}\text { Parenteral } \\
\text { nutritional sup- } \\
\text { port } 6-8 / 6-7 \\
\text { Enteral } 6-8 / 6-7\end{array}$ & $\begin{array}{l}(25) \\
(27)\end{array}$ & $\begin{array}{l}24(96) \\
23(85)\end{array}$ & $\begin{array}{ll}1 & (4) \\
4 & (15)\end{array}$ \\
\hline 48 & $\begin{array}{l}\text { Parenteral } \\
\text { nutritional sup- } \\
\text { port } 0 / 18 \\
\text { Control }\end{array}$ & $\begin{array}{l}(18) \\
(16)\end{array}$ & $\begin{array}{l}18(100) \\
15(94)\end{array}$ & $\begin{array}{ll}0 & (0) \\
5 & (31)\end{array}$ \\
\hline 49 & $\begin{array}{l}\text { Parenteral } \\
\text { nutritional sup- } \\
\text { port } 5-7 / 6-7 \\
\text { Control }\end{array}$ & $\begin{array}{l}(10) \\
(5)\end{array}$ & $\begin{array}{r}10(100) \\
5(100)\end{array}$ & $\begin{array}{ll}0 & (0) \\
1 & (20)\end{array}$ \\
\hline 50 & $\begin{array}{l}\text { Parenteral } \\
\text { nutritional sup- } \\
\text { port } 7-10 / 7-10 \\
\text { Parenteral } \\
\text { nutritional sup- } \\
\text { port } 0 / 7-10 \\
\text { Control }\end{array}$ & $\begin{array}{l}(10) \\
(10)\end{array}$ & $\begin{array}{l}9(90) \\
9(90)\end{array}$ & "More" \\
\hline 51 & $\begin{array}{l}\text { Parenteral } \\
\text { nutritional sup- } \\
\text { port } 14 / 0 \\
\text { Control }\end{array}$ & $\begin{array}{l}(8) \\
(7)\end{array}$ & $\begin{array}{l}8(100) \\
7(100)\end{array}$ & $\begin{array}{l}3(38) \\
4(57)\end{array}$ \\
\hline
\end{tabular}

The numerator of the fraction indicates days of preoperative nutritional support, the denominator days of postoperative support: *numbers of complications assumed one complication per patient; ${ }^{* *} \mathrm{p}<(0) \cdot 05$. 
nutrition, and in five of six other reports a lower morbidity was also associated with the use of parenteral nutrition. Parenteral nutrition may, therefore, provide a small benefit, but the numbers of patients studied may have been inadequate to show this statistically (type İ error).

To obtain some data concerning potential cost and benefit the reported morbidities and mortalities were weight averaged. The total postoperative complication rates were calculated to be $54 \%$ (control) and 22\% (recipients of parenteral nutrition). In Cardiff and West Germany about $40 \%$ of the complications were minor and were reduced by about $75 \%$ using parenteral nutrition; the major complication rate was roughly halved. Using cost data derived by Twomey and Patching, ${ }^{52}$ the calculation outlined in Table 2 can be made. From a cost perspective, the overall result seems to make little difference. It could be argued that for an extra $\$ 200$ per patient, substantial pain and suffering is avoided (assuming the extra postoperative complications in some constitute more pain and suffering than preoperative parenteral nutrition in all).

Weight averaging the survival statistics indicates that the postoperative mortality may be reduced from 14 to $7 \%$. This must be taken in the context of the underlying disease. The natural history of these operated malignancies is that just under $50 \%$ of the patients die in the first year, $50 \%$ in the next year, and most of the remainder in the next two to three years. ${ }^{53} 54$ Assuming that preoperative parenteral nutrition has no influence on this natural history, survival curves can be constructed (Table 3). As

Table 2 Cost effectiveness of providing parenteral nutrition in surgical patients with upper gastrointestinal cancer

\section{Assumptions:}

1 Ten days preoperative parenteral nutritional support to all patients

2 Provision of parenteral nutritional support will reduce complication rates

Minor complications: $20 \%$ without parenteral nutritional support, $5 \%$ with parenteral nutritional support

Major complications: $30 \%$ without parenteral nutritional support, $15 \%$ with parenteral nutritional support

3 Costs

(i) One day hospital stay with total parenteral nutrition

(ii) Minor complication

(iii) Major complication

$\$ 800$

$\$ 2000$

$\$ 50000$

Costs of providing parenteral nutritional support to 100 patients: 100 patients receiving 10 days each $\$ 800000$ Reduction of $15 \%$ in minor complications Reduction of $15 \%$ in major complications Net cost

$-30000$

$-750000$

$\$ 20000$
Table 3 Difference in long term survival using preoperative parenteral nutrition in upper gastrointestinal malignancies (expressed as percentage)

\begin{tabular}{|c|c|c|}
\hline \multirow[b]{2}{*}{ Time period } & \multicolumn{2}{|l|}{ Cumulative mortality* } \\
\hline & $\begin{array}{l}\text { Parenteral nutritional } \\
\text { support used }\end{array}$ & $\begin{array}{l}\text { Parenteral nutritional } \\
\text { support not used }\end{array}$ \\
\hline Perioperative & $7 \cdot 0$ & $14 \cdot 0$ \\
\hline End of year 1 & $53 \cdot 5$ & $57 \cdot 0$ \\
\hline End of year 2 & $76 \cdot 8$ & $79 \cdot 5$ \\
\hline End of year 3 & $86 \cdot 0$ & $87 \cdot 1$ \\
\hline End of year 5 & $9(0 \cdot 7$ & 91.4 \\
\hline
\end{tabular}

*Assumes all surgical survivors in both groups have following mortality: 1 year $50 \% ; 1-2$ years $25 \% ; 2-3$ years $10 \% ; 3-5$ years $5 \%$; "curc" $10 \%$.

only $10 \%$ of these patients are predicted to be cured, the $7 \%$ reduction in operative mortality only provides $0.7 \%$ of cured patients. For the average patient going to surgery provision of parenteral nutrition will give an additional two months of life (Table 4).

Trials of enteral feeding have also been conducted for perioperative patients. The liquid diets provided no particular advantage over routine bowel preparation. ${ }^{55-58}$ In fact, in one of these studies the recipients of the elemental diets had more complications and a longer hospital stay. ${ }^{58}$ Two other trials evaluated the use of these residue free liquid diets as "medical colostomies" in patients undergoing anorectal surgery. ${ }^{59}{ }^{60}$ Although there was a reduced analgesic requirement associated with the use of the liquid feeding, ${ }^{59}$ the cost of the diet is greater than the cost of the one additional daily injection.

Several prospective randomised controlled trials of immediate postoperative small intestinal feedings

Table 4 Projected No of patient months of survival

\begin{tabular}{|c|c|c|c|c|}
\hline \multirow[b]{2}{*}{ Time period } & \multirow{2}{*}{$\begin{array}{l}\text { Parenteral } \\
\text { patients } \\
\text { Deaths } \\
(\%)\end{array}$} & nutrition & \multicolumn{2}{|c|}{ Control patients } \\
\hline & & $\begin{array}{l}\text { Patient } \\
\text { months } \\
\text { of life } e^{*}\end{array}$ & $\begin{array}{l}\text { Deaths } \\
(\%)\end{array}$ & $\begin{array}{l}\text { Patient } \\
\text { months } \\
\text { of life }\end{array}$ \\
\hline $\begin{array}{c}\text { Postoperative } \\
\text { (1 month) }\end{array}$ & $7 \cdot 00$ & 0.035 & $14 \cdot 00$ & $0 \cdot(070$ \\
\hline $1-12$ months & $46 \cdot 50$ & $3 \cdot(023$ & $43 \cdot 00$ & 2.795 \\
\hline 13-24 months & $23 \cdot 25$ & $4 \cdot 185$ & $21 \cdot 50$ & $3 \cdot 870$ \\
\hline 25-36 months & $9 \cdot 30$ & $2 \cdot 790$ & $8 \cdot 60$ & $2 \cdot 580$ \\
\hline $37-60$ months & $4 \cdot 65$ & $2 \cdot 232$ & $4 \cdot 30$ & $2 \cdot() 64$ \\
\hline "Cure" & $9 \cdot 30$ & $16 \cdot 740$ & $8 \cdot 60$ & $15 \cdot 480$ \\
\hline Total & $100 \cdot 00$ & $29 \cdot 005$ & $100 \cdot 00$ & $26 \cdot 859$ \\
\hline
\end{tabular}

*Calculated by assuming average duration of life was a time halfway between beginning and end of time period; cured patients assumed to live average total of 15 years. 
showed improvements in nitrogen balance. ${ }^{61-63}$ Unfortunately, these studies, as well as a fourth, ${ }^{64}$ failed to show a concomitant reduction in postoperative complications. Two of these trials found that the recipients of the tube feedings required five to six days less of intravenous fluids. ${ }^{62}{ }^{64}$ The extra cost of placing the tube (about \$150) more than compensates for the small differences in the cost of a litre of each solution ( $\$ 21$ for intravenous, $\$ 15$ for enteral). Three of these trials ${ }^{61-63}$ considered the effect of these feedings on duration of hospital stay; while two found no difference, one ${ }^{61}$ reported a reduction of five days. Clearly, the savings to be gained by such a reduction in hospital stay would more than compensate for the expense incurred. It still remains to be confirmed, however, whether these feedings will reduce hospital stay.

In support of the notion that such feedings may be beneficial after trauma nocturnal nasogastric tube feedings of a liquid diet were shown to promote faster rehabilitation in "very thin" (two standard deviations below the mean) elderly women with hip fractures. ${ }^{65}$ This effect was not seen in the better nourished patients.

\section{Inflammatory bowel disease}

Two trials of parenteral nutrition in inflammatory bowel disease (Crohn's disease or ulcerative colitis, or both) failed to show any clinical effect of this form of treatment. ${ }^{66} 67$ Both these studies were conducted on patients with active disease.

Two trials of enteral nutrition in Crohn's disease have been reported. ${ }^{68}{ }^{69}$ In one, a crossover trial, there was no appreciable difference in clinical activity index when the patient was on a liquid nutritional supplement. ${ }^{68}$ In the other a four week course of an elemental diet was as effective as corticosteroids in controlling acute bouts of Crohn's enteritis. The patients in the group given the elemental diet did not consume any food other than the elemental diet for two weeks; even including this saving the cost of the elemental diet would be 33\% more than that of corticosteroids and food (Table 5).

None of these trials addresses the issue of patients who are long term nutritional cripples because of their inflammatory bowel disease.

\section{Special amino acid preparations}

Two special amino acid formulations have become available: essential amino acids (EAA) in renal failure; and branched chain amino acids (BCAA) in hepatic encephalopathy. (BCAA has also been advocated for physiologically stressed patients, but
Table 5 Cost comparison of corticosteroids and elemental diet in treating Crohn's disease

\begin{tabular}{|c|c|c|}
\hline \multirow[b]{2}{*}{ Item } & \multicolumn{2}{|c|}{ Cost* (in US dollars) $^{*}$} \\
\hline & Elemental diet & Corticosteroids \\
\hline Corticosteroid & & 16 \\
\hline Food (two weeks) & & 140 \\
\hline $\begin{array}{l}\text { Corticosteroid } \\
\text { complication }\end{array}$ & & 750 \\
\hline Elemental diet & 1215 & \\
\hline Total & 1215 & 906 \\
\hline
\end{tabular}

*Assumes: (i) Steroids given for 12 weeks in tapering doses $50 \mathrm{mg} /$ day to $20 \mathrm{mg} /$ day, then discontinued shortly thereafter); (ii) food costs \$10/day; (iii) probability of corticosteroid complication estimated (probably excessively) to be $10 \%$ for "minor" (cost $=\$ 2000)$ and $1 \%$ for "major" (cost $=\$ 50000)$; (iv) clemental diet costs $\$ 15 /$ litre ( 1 litre on day 1, 2 litres on day 2, then 3 litres on days 3-30).

this indication will not be considered in the absence of prospective randomised controlled trials.) Two distinct issues are raised in the use of these preparations, questions which are often blurred by study designs. The first is whether the particular preparation is, in itself, effective (as a "medication") in treating these disease states; the second is whether the addition of a programme of nutritional support (including calories, vitamins, etc.) is more effective.

ESSENTIAL AMINO ACIDS

Four trials have assessed the value of EAA in acute renal failure $e^{7(-73}$ (Table 6). In the largest study there was a considerable improvement in survival from the acute episode $(75 \% \vee 44 \%)$, although only an

Table 6 Use of essential amino acids in acute renal failure

\begin{tabular}{|c|c|c|c|c|}
\hline \multirow[b]{2}{*}{ Reference } & \multirow{2}{*}{\multicolumn{2}{|c|}{ Treatment $(n=)$}} & \multicolumn{2}{|l|}{ Survival } \\
\hline & & & $\begin{array}{l}\text { Acute+ } \\
(\%)\end{array}$ & $\begin{array}{l}\text { Discharge } \\
(\%)\end{array}$ \\
\hline \multirow[t]{2}{*}{70} & $47 \% \mathrm{D}+\mathrm{EAA}$ & (28) & $21(75)^{*}$ & $17(61)$ \\
\hline & $50 \% \mathrm{D}$ & (25) & $11(44)$ & $10(40)$ \\
\hline \multirow[t]{2}{*}{71} & $47 \% \mathrm{D}+\mathrm{EAA}$ & (11) & $6(55)$ & $4(36)$ \\
\hline & $47 \% \mathrm{D}$ & (9) & $5(56)$ & $4(44)$ \\
\hline \multirow[t]{3}{*}{72} & $36 \% \mathrm{D}+\mathrm{EAA}$ & (7) & $5(71)$ & $5(71)$ \\
\hline & $36 \% \mathrm{D}+\mathrm{ENAA}$ & (9) & $3(33)$ & $3(33)$ \\
\hline & $37 \cdot 5 \% \mathrm{D}$ & (7) & $2(29)$ & $2(29)$ \\
\hline \multirow[t]{3}{*}{73} & $41 \% \mathrm{D}+\mathrm{EAA}$ & (3) & NS & $0(0)$ \\
\hline & $43 \% \mathrm{D}+\mathrm{ENAA}$ & (2) & NS & () $(0)$ \\
\hline & $44 \% \mathrm{D}$ & (1) & NS & () (0) \\
\hline
\end{tabular}

EAA = essential amino acids; $E N A A=$ essential and non-essential amino acids; $D=$ dextrose; NS=not stated. ${ }^{+}$Survived acute episode reneal failure. ${ }^{*} \mathrm{p}<0 \cdot 05$. 
Table 7 Use of Branched chain amino acids in hepatic encephalopathy

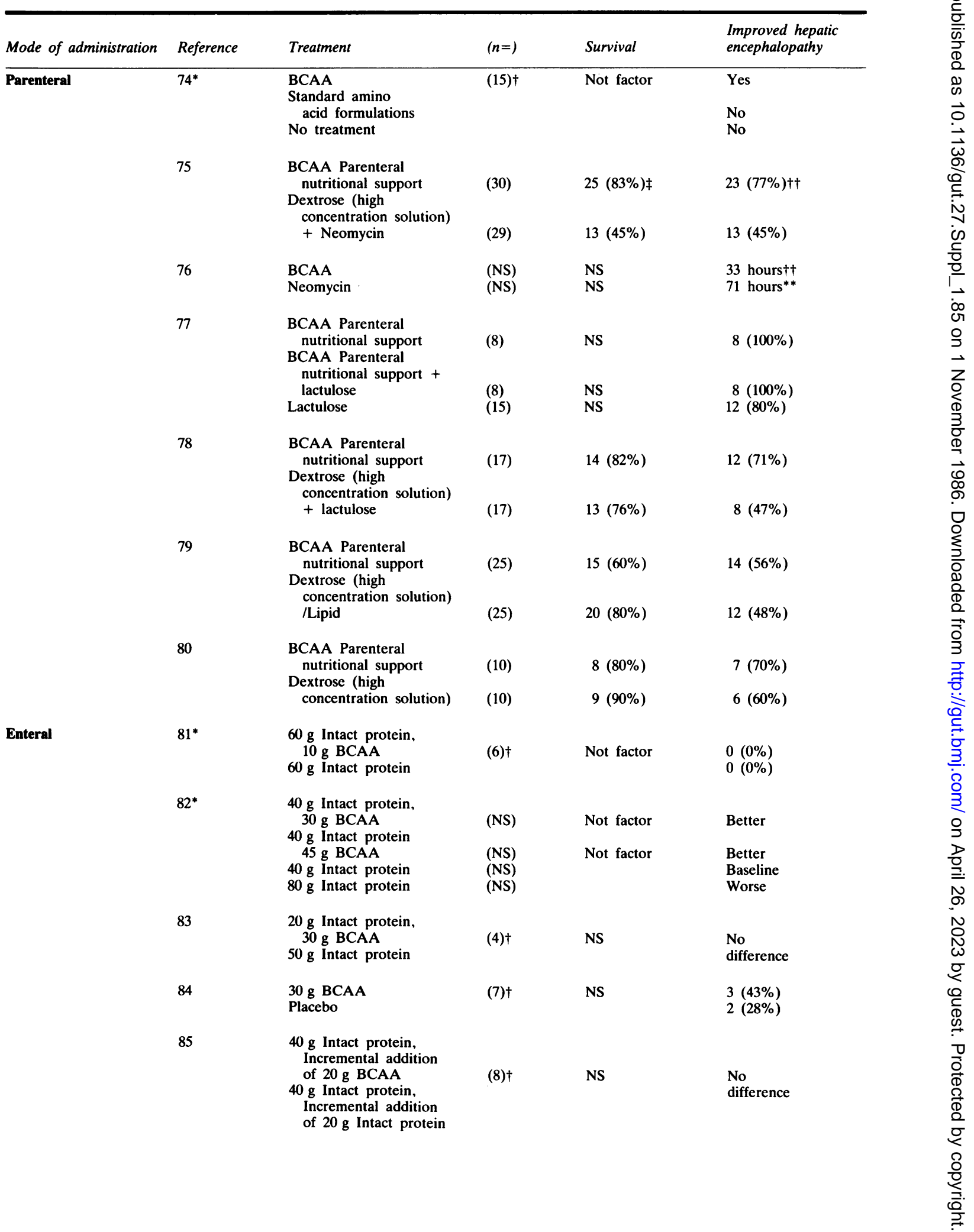


Table 7 - cont.

\begin{tabular}{|c|c|c|c|c|c|}
\hline Mode of administration & Reference & Treatment & $(n=)$ & Survival & $\begin{array}{l}\text { Improved hepatic } \\
\text { encephalopathy }\end{array}$ \\
\hline & 86 & $\begin{array}{l}\text { 20) } \mathrm{g} \text { Intact protein. } \\
\text { Incremental addition of } \\
20 \mathrm{~g} \mathrm{BCAA} \\
20 \mathrm{~g} \text { Intact protein. } \\
\text { Incremental protein of } \\
20 \mathrm{~g} \text { Intact protein }\end{array}$ & $\begin{array}{l}\text { (14) } \\
\text { (12) }\end{array}$ & $\begin{array}{l}\text { NS } \\
\text { NS }\end{array}$ & $\begin{array}{l}13(93 \%)+\dagger \\
5(42 \%)\end{array}$ \\
\hline
\end{tabular}

$\mathrm{BCAA}=$ Branched chain amino acids (Formulations may be pure branched chain amino acids or branched chain amino acid enriched) NS $=$ not stated.

${ }^{*}$ Patients with latent hepatic encephalopathy, measured by psychometric testing.

tStudy design crossover rather than randomisation to one or other treatment arm. $\ddagger \mathrm{p}<0 \cdot 01$.

$\dagger \dagger \mathrm{p}<0 \cdot(05$

**Improvement in hepatic encephalopathy calculated as time for hepatic encephalopathy to resolve

arithmetically better hospital discharge survival rate $(61 \% v 40 \%)$ in those receiving EAA. " This effect was especially noticeable in those patients who required dialysis. Surprisingly, in a similar protocol, evaluating only patients who required dialysis, these data could not be reproduced..$^{71}$ A third small trial ${ }^{72}$ showed an arithmetic trend in the same direction as the first $;{ }^{70}$ in the smallest of all the studies to be discussed in this paper (six patients divided into three treatment arms) there were no survivors. ${ }^{73}$

These acute renal failure protocols are also difficult to interpret because of the treatment given to the control groups. In all four studies those not receiving amino acids were given high concentrations (usually even higher than those given to patients receiving amino acids) dextrose infusions. This osmotic load might be a problem in patients who are oliguric.

If EAA solutions really do save lives in acute renal failure they should be used, but at present, this has not been confirmed. We will need at least one more large study to attempt to settle the issue. Ideally it should include two groups receiving the essential amino acids (one with and one without large concentrations of dextrose to address the question of the addition of nutritional support), and a control group receiving truly standard care.

\section{BRANCHED CHAIN AMINO ACIDS}

A large number of prospective randomised controlled trials have addressed the issue of the use of BCAA in hepatic encephalopathy (Table 7). ${ }^{74} 86$ These studies usually used different BCAA preparations, some of which were BCAA only and others of which were enriched with BCAA.

The only trial to show a significant difference in survival was the multicentre American trial. ${ }^{75}$ Two of the other studies in which survival data were available found that arithmetical reductions in this variable were associated with the use of the BCAA solutions: interestingly, an earlier abstract (Hagenfeldt $e t$ al. Fourth symposium in intensive care in hepatology and gastroenterology, 1981) ${ }^{87}$ of one of these studies, ${ }^{79}$ reporting on a larger number of patients(!), found that the reduced rate of survival was significant.

The seven parenteral trials do share one thing in common: in all, those receiving BCAA had at least an arithmetical improvement in hepatic encephalopathy. The probability of all seven studies showing the same arithmetical trend, if there was no therapeutic benefit or detriment to the BCAA solution, would be the same as having a coin come up either heads or tails seven times in a row; this probability is $0 \cdot 016$. If we are again observing type II errors intravenous BCAA solutions may have some potential therapeutic value in treating hepatic encephalopathy. (Although one of the enteral trials also showed a beneficial effect of BCAA feedings on encephalopathy when a BCAA based elemental diet was fed instead of protein for several weeks, the data from the other trials do not clarify the reproducibility of this observation.)

These parenteral trials do suffer from the same drawbacks discussed above as those for EAA and acute renal failure. Are BCAA solutions in and of themselves therapeutic, and what (if anything) is to be gained by adding a programme of parenteral nutritional support? Was the administration of high concentration dextrose solutions to the control group detrimental? (The 55\% mortality in the cooperative trial ${ }^{75}$ may have been excessive.) Are BCAA solutions more effective than the standard antiencephalopathic lactulose therapies, or neomycin?

The daily costs of these three agents at my 
Table 8 Cost comparisons for treating hepatic encephalopathy*

\begin{tabular}{lll}
\hline Treatment Regimen & $\begin{array}{l}\text { Dollar } \\
\text { costs }\end{array}$ & $\begin{array}{l}\text { Days of } \\
\text { hepatic } \\
\text { encephalopathy }\end{array}$ \\
\hline $\begin{array}{l}\text { Neomycin } \times 4 \text { days, BCAA } \times \\
\quad \text { days to non-responder }\end{array}$ & $56 \cdot 40$ & $3 \cdot 45$ \\
$\begin{array}{l}\text { Lactulose } \times 4 \text { days, BCAA } \times \\
2 \text { days to non-responder }\end{array}$ & $70 \cdot 40$ & $3 \cdot 45$ \\
$\begin{array}{c}\text { BCAA } \times 2 \text { days, neomycin } \times 4 \\
\text { days to non-responder }\end{array}$ & $126 \cdot 0$ & $2 \cdot 25$ \\
\hline
\end{tabular}

*Assumes: (i) efficacy and length of treatment of neomycin. rifiomycin, lactulose, and lactulose, and branched chain amino acid solution as stated in text (optimistic estimate); (ii) no impact of hepatic encephalopathy treatment on mortality or duration of hospital stay; (iii) cost of neomycin, lactulose and branched chain amino acid solution as stated in text.

hospital are: neomycin $(4 \mathrm{~g}) \$ 1 \cdot 00$; lactulose $(200 \mathrm{~g})$ (a large dose), $\$ 5 \cdot 10$; intravenous BCAA solution (amino acid solution alone) (40 g), $\$ 62 \cdot 50$. If these are equally effective it is obviously costly to use the BCAA solution. Table 8 makes a cost comparison, assuming that the BCAA solution is more effective $(75 \%)$ than either lactulose or neomycin $(60 \%)$, and, furthermore, that it only need be administered for two days instead of four. Even under these optimistic conditions, it is still more expensive to begin treatment with BCAA solutions. As is seen, the extra price may result in a shorter duration of encephalopathy. (These patients usually have complicated liver disease and other problems, and there is no reason to assume that the earlier resolution of encephalopathy will translate into a shorter hospital stay.)

\section{Other prospective randomised controlled trials}

Six studies have considered the use of parenteral nutrition in low birth weight infants $;{ }^{87-92}$ in only one of these was there overt concomitant illness respiratory failure. ${ }^{87}$ Parenteral nutrition did not affect survival in any of the trials. Although there were fewer days with apnoea in a group of infants who received parenteral nutrition compared with those of the control infants, ${ }^{88}$ in another trial the babies receiving parenteral nutrition had an overall increase in various complications. ${ }^{89}$ As parenteral nutrition may be associated with more rapid weight gain could the use of it at least be associated with a shorter hospital stay, as weight is the discharge criterion in these children? In fact, faster weight gain was seen in four of the five reports for which this variable was measured (faster ${ }^{88-91} ;$ no difference ${ }^{y 2}$ ). In spite of this there was no difference in overall duration of hospital stay in the three trials for which this information was available. ${ }^{89-91}$

Three trials have assessed the use of parenteral amino acids in alcoholic hepatitis (with or without an energy source). ${ }^{93-95}$ Although the differences in survival in one $\left(100 \% v 78 \%{ }^{{ }^{3}}\right)$ were reported as significant, in fact, this is not the case when the calculation is corrected for the small numbers of patients $(p=0 \cdot 13)$. Two of the trials ${ }^{9394}$ found a faster fall in the serum bilirubin concentration in association with the use of the amino acids, but it was not shown that this biochemical phenomenon correlated with any important clinical event. ${ }^{94}$ )

Small trials of parenteral nutrition in burn patients ${ }^{96}$ and those with acute pancreatitis ${ }^{97}$ have been conducted. No differences between outcome were noted. Elemental diets were evaluated as treatment for asthma; ${ }^{98}$ although favourable results were reported, based on a numerical improvement in a symptom score, the authors happened to have picked the only such symptom score in which the differences were significant.

Finally, one trial was conducted in patients with head injuries. ${ }^{99}$ They were randomised to receive parenteral or entral nutrition (via nasogastric tube feedings). A difference between survivals was observed, favouring the recipients of parenteral nutrition. From the study design, however, it was impossible to say whether parenteral nutrition was good or enteral nutrition bad. Based on the historical experience from the same institution, ${ }^{100}$ it could be calculated that the enteral feeding was more likely to have produced an adverse effect than was parenteral feeding to have produced a beneficial one. ${ }^{102}$

\section{Inadequate bowel syndrome}

There are patients in whom the capacity to maintain their nutritional state is permanently lost. Although the term "short bowel syndrome" is often applied, the intestine is sometimes anatomically present (albeit non-functional), and the term "inadequate bowel syndrome" seems to be more appropriate. Patients so diagnosed will, by definition, die of starvation unless programmes of nutritional support are given. It would be unethical to conduct prospective randomised controlled trials to prove that life is prolonged. It is assumed that the parenteral nutriion is effective, and the cost of these programmes therefore becomes a societal issue.

Some patients do not have permanent inadequate bowel, but they can be predicted to have (or have already shown) protracted problems. A special example of this is growth retardation in adolescents 
with various gastrointestinal disorders. Again, the problems inherent in growth retardation are well defined, and nutritional support during these growth years is known to reverse the problem.

This does lead to the more general issue of deciding how long is too long to go without adequate nutrition. It is clear from our clinical experience that any well nourished subject can tolerate several days of nutritional deprivation. What we don't know is how long this can go on before the problems presented by the malnutrition detrimentally affect those of the underlying disease. The failure of most of the prospective randomised controlled trials to show an effect suggests that in many of these patients the impact of the associated malnutrition is small. To make rational decisions about these expensive nutritional treatment regimens we need to know how long is too long to go without nutritional supplementation.

\section{Conclusions}

The above analysis was of prospective randomised controlled trials. The studies, however, were grouped in an attempt to find possible areas of benefit. This is, in effect, a retrospective review of the prospectively collected data. The analogy to the coin flip should be modified; a more appropriate consideration would be that I have reviewed a sequence of coin flips, found parts of that sequence where the coin flips seemed to have defied statistical probablility, and then asked if the coin was somehow loaded. In fact it may or may not have been. Retrospective reviews must be confirmed by prospective trials.

It is obvious that nutritional support supports nutrition. It is also clear that most of the attempts to prove that this support can be translated into beneficial clinical outcome have not been successful. This should not be interpreted as meaning that no benefit exists. Many of the trials studied small numbers of patients; less than significant differences might have been missed. On the other hand, it must be apparent that nutritional support will not provide huge benefits. We must approach nutritional support with the same clinical scepticism and objectivity that we approach other proposed treatment regimens. Certainly, if nutritional support had come on the market as a drug, the Food and Drug Administration in the United States would never have accepted it. Data from large prospective randomised controlled trials proving or disproving the various proposed applications of nutrition support are needed; its cost effectiveness must then be established where clinical efficacy is shown.

\section{References}

1 Studley HO. Percentage of weight loss. JAMA 1936; 106: $458-60$.

2 Popp MB, Fisher RI, Wesley R, Aamodt R, Brennan MF. A prospective randomized study of adjuvant parenteral nutrition in the treatment of advanced diffuse lymphoma: influence on survival. Surgery 1981; 90: 195-203.

3 Popp MB, Fisher RI, Simon RM, Brennan MF. A prospective randomized study of adjuvant parenteral nutrition in the treatment of diffuse lymphoma: effect on drug tolerance. Cancer Treat Rep 1981; 65 (Suppl 5): $129-135$.

4 Nixon DW, Mottiff S, Lawson DH, et al. Total parenteral nutrition as an adjunct to chemotherapy of metastic colorectal cancer. Cancer Treat Rep 1981; 65 (Suppl 5): 121-8.

5 Samuels ML, Selig DE, Ogden S, Grant C, Brown B. IV hyperalimentation and chemotherapy for stage III testicular cancer: a randomized study. Cancer Treat Rep 1981; 65: 615-27.

6 Shamberger RC, Brennan MF, Goodgame JT, et al. A prospective randomized study of adjuvant parenteral nutrition in the treatment of sarcomas: results of metabolic and survival studies. Surgery 1984; 96: 1-12.

7 Shamberger RC, Pizzo PA, Goodgame JT, et al. The effect of total parenteral nutrition in chemotherapyinduced myelosuppression. Am J Med 1983; 74: 40-8.

8 Isell $\mathrm{BF}$, Valdivieso M, Zaren HA, et al. Protection against chemotherapy toxicity by IV hyperalimentation. Cancer Treat Rep 1978; 62: 1139-43.

9 Coquin JY, Maraninchi D, Gastaut JA, Carcassone Y. Influence of parenteral nutrition (P.N.) on chemotherapy and survival of acute leukemia (A.L.); preliminary results of a randomized trial. JPEN 1981; 5: 357.

10 Serrou B, Cupissol D, Plagne R, et al. Follow-up of a randomized trial for oat cell carcinoma evaluating the efficacy of peripheral intravenous nutrition (PIVN) as adjunct therapy. Recent Results Cancer Res 1982; 80: 246-53.

11 Valdivieso M, Bodey GP, Benjamin RS, et al. Role of intravenous hyperalimentation as an adjunct to intensive chemotherapy for small cell bronchogenic carcinoma. Cancer Treat Rep 1981; 65 (Suppl 5): 145-50.

12 Shike M, Feld R, Evans WK, Shepherd FA, Harrison $\mathrm{JE}$, Jeejeebhoy $\mathrm{KN}$. Long term effect of TPN on body composition of patients with lung carcinoma. JPEN 1981; 5: 564.

13 Jordan WM, Valdivieso M, Frankmann C, et al. Treatment of advanced adenocarcinoma of the lung with ftoratur, doxorubicin, cyclophosphamide, and cisplatin (FACP) and intensive iv hyperalimentation. Cancer Treat Rep 1981; 65: 197-205.

14 Lanzotti V, Copeland E, Bhuchar V, Wesley M, Corriere J, Dudrick S. A randomized trial of total parenteral nutrition (TPN) with chemotherapy for non-oat cell lung cancer (NOCLC). Proceedings of the American Association for Cancer Research and the American Society of Clinical Oncology 1980; 21: 377.

15 Van Eys J, Copeland EM, Cangir A, et al. A clinical 
trial of hyperalimentation in children with metastatic malignancies. Med Pediatr Oncol 1980; 8: 63-73.

16 Hays DM, Merritt RJ, White L, Ashley J, Siegel SE. Effect of total parenteral nutrition on marrow recovery during induction therapy for acute nonlymphocytic leukemia in childhood. Med Pediatr Oncol 1983; 11: $139-40$.

17 Solassol C, Joyeux H, Dubois J-B. Total parentral nutrition (TPN) with complete nutritive mixtures: an artificial gut in cancer patients. Nutr Cancer 1979: 1: 13-8.

18 Kinsella TJ, Malcolm AW, Bothe A, Valerio D, Blackburn GL. Prospective study of nutritional support during pelvic irradiation. Int J Radiat Oncol Biol Phys 1981; 7: 543-8.

19 Donaldson SS, Wesley MN, Ghavimi F, Shils M, Suskind RM, De Wys WD. A prospective randomized clinical trial of total parenteral nutrition in children with cancer. Med Pediatr Oncol 1982; 10: 129-39.

20 Ghavimi F, Shils ME, Scott BF, Brown M, Tamaroff $M$. Comparison of morbidity in children requiring abdominal radiation and chemotherapy with and without total parenteral nutrition. J Pediatr 1982; 101: 530-7.

21 Valerio D, Overett L, Malcolm A, Blackburn GL. Nutritional support for cancer patients receiving abdominal and pelvic radiotherapy: a randomized prospective clinical experiment of intravenous versus oral feeding. Surgical Forum 1978; 29: 145-8.

22 Shike M. Total parenteral nutrition in patients with lung cancer. Congress of parenteral nutrition. 7th clinical congress. Washington, DC: American Society for Parenteral and Enteral Nutrition, 1983: 36.

23 Bounous B, Le Bel E, Shuster J, Gold P, Tahan WT, Bastin E. Dietary protection during radiation therapy. Strahlentherapie 1975; 149: 476-83.

24 Douglass HO, Milliron S, Nava H, et al. Elemental diet as an adjuvant for patients with locally advanced gastrointestinal cancer receiving radiation therapy: a prospectively randomized study. JPEN 1978; 2: 682-6.

25 Brown MS, Buchanan RB, Karran SJ. Clinical observations on the effects of elemental diet supplementation during irradiation. Clin Radiol 1980; 31: 19-20.

26 Cousineau L, Bounous G, Rochon M, Shuster J, Gold $P$, Tahan $W$. The use of an elemental diet during treatment with anticancer agents. Clin Res 1983; 21: 1067.

27 Bounous G, Gentile JM, Hugon J. Elemental diet in the management of the intestinal lesion produced by 5-fluorouracil in man. Can J Surg 1971; 14: 312-24.

28 Lipschitz DA, Mitchell CO. Enteral hyperalimentation and hematopoietic toxicity caused by chemotherapy of small cell lung cancer. JPEN 1980; 4: 593.

29 Elkort RJ, Baker FL, Vitale JJ, Cordano A. Longterm nutritional support as an adjunct to chemotherapy for breast cancer. JPEN 1981; 5: 385-90.

30 Moloney M, Moriarty M, Daly L. Controlled studies of nutritional intake in patients with malignant disease undergoing treatment. Hum Nutr Appl Nutr 1983; 37A: $30-5$.
31 Hensle TW. Protein-sparing in cystectomy patients. J Urol 1978; 119: 355-8.

32 Garden OJ, Smith A, Harris NWS, Shenkin A, Sim AJW, Carter DC. The effect of isotonic amino acid infusions on serum proteins and muscle breakdown following surgery. Br J Surg 1983; 70: 79-82.

33 Hogbin BM, Smith AM, Craven AH. Evaluation of peripheral essential amino acid infusion following major surgery. JPEN 1984; 8: 511-4.

34 Sako K, Lore JM, Kaufman S, Razack MS, Bakamjian V, Reese P. Parenteral hyperalimentation in surgical patients with head and neck cancer: a randomized study. J Surg Oncol 1981; 16: 391-402.

35 Simms JM, Smith JAR. Intravenous feeding after total cystectomy - a controlled trial. JPEN 1981: 5: 357.

36 Abel RM, Fischer JE, Buckley MJ, Barnett GO, Austen WG. Malnutrition in cardiac surgical patients. Arch Surg 1976; 111: 45-50.

37 O'Mahony JB, McIrvine AJ, Palder SB, et al. The effect of short term postoperative intravenous feeding upon cell-mediated immunity and serum suppressive activity in well nourished patients. Surg Gynecol Obstet 1984; 159: 27-32.

38 Collins JP, Oxby CB, Hill GL. Intravenous aminoacids and intravenous hyperalimentation as proteinsparing therapy after major surgery. Lancet 1978; i: 188-91.

39 Preshaw RM, Attisha RP, Hollingsworth WJ, Todd JD. Randomized sequential trial of parenteral nutrition in healing of colonic anastomoses in man. Can J Surg 1979; 22: 437-9.

40 Jensen $S$. Parenteral nutrition and cancer surgery. JPEN 1982: 6: 335 .

41 Holter AR, Fischer JE. The effects of perioperative hyperalimentation on complications in patients with carcinoma and weight loss. J Surg Res 1977; 23: 31-4.

42 Thompson BR, Julian TB, Stremple JF. Perioperative total parenteral nutrition in patients with gastrointestinal cancer. J Surg Res 1981; 30: 497-500.

43 Muller J, Brenner U, Dienst C, Pichlmaier $H$. Preoperative parenteral feeding in patients with gastrointestinal carcinoma. Lancet 1982; i: 68-72.

44 Mueller JM, Brenner MD, Roeckl-Mueller C, Pichlmaier $\mathrm{H}$. Preoperative parenteral nutrition in surgery for carcinoma of the upper GI tract - a prospective randomized trial. JPEN 1981; 5: 570.

45 Heatley RV, Williams RHP, Lewis MH. Preoperative intravenous feeding - a controlled trial. Postgrad Med J 1979; 55: 541-5.

46 Lim STK, Choa RG, Lam KH, Wong J, Ong GB. Total parenteral nutrition versus gastrostomy in the preoperative preparation of patients with carinoma of the oesophagus. Br J Surg 1981; 68: 69-72.

47 Moghissi M, Teasdale P, Dench M. Comparison between pre-operative enteral (naso-gastric tube) and parenteral feeding in patients with cancer of the oesophagus undergoing surgery. JPEN 1982; 6: 335.

48 Yamada N, Koyama H, Hioki K, Yamada T, Yamamoto M. Effect of postoperative total parenteral nutrition (TPN) as an adjunct to gastrectomy for 
advanced gastric carcinoma. Br J Surg 1983; 70: 267-74.

49 Moghissi K, Hornshaw J, Teasdale PR, Dawes EA. Parenteral nutrition in carcinoma of the oesophagus treated by surgery: nitrogen balance and clinical studies. Br J Surg 1977; 64: 125-8.

50 Simms JM, Oliver E, Smith JAR. A study of total parenteral nutrition (TPN) in major gastric and esophageal resection for neoplasia. JPEN 1980; 4: 422.

51 Schildt B, Groth O, Larsson J, Sjodahl R, Symreng T, Wetterfors J. Failure of preoperative TPN to improve nutritional status in gastric carcinoma. JPEN 1981; 5: 360.

52 Twomey PL, Patching SC. Cost-effectiveness of nutritional support. JPEN 1985: 9: 3-10.

53 Gunnlaugson GH, Wychulis AR, Roland C, Ellis FH. Analysis of the records of 1,657 patients with carcinoma of the esophagus and cardia of the stomach. Surg Gynecol Obstet 1970; 130: 997-1005.

54 Ellis FH. Carcinoma of the esophagus. $C A$ 1983; 33: 264-81.

55 Trague RM, Salmon PR, Read AE. Fibreoptic examination of the colon: a review of 255 cases. Gut 1973; 14: 139-42.

56 Tomlinson RJR, Newman BM, Schofield PF. Is colostomy closure a hazardous procedure? A comparison of elemental diet and routine bowel preparation. Br J Surg 1976; 63: 799-800.

57 Gurry JF, Ellis-Pegler RB. An elemental diet as preoperative preparation of the colon. Br J Surg 1976; 63: 969-72.

58 Matheson DM, Arabi Y, Baxter-Smith D, AlexanderWilliams J, Keighley MRB. Randomized multicentre trial of oral bowel preparation and antimicrobials for elective colorectal operations. Br J Surg 1978; 65: 597-600.

59 Crossland SG, Geelhoed GW, Guy DG. Evaluation of benefits of different nutritional pre- and postoperative management of hemorrhoidectomy patients. American Journal of Proctology, Gastroenterology, and Rectal Surgery 1978; 32(5):8-14.

60 Baker FS. Elemental diet and postoperative pain. Dis Colon Rect 1978, 21: 535.

61 Sagar S, Harland P, Shields R. Early postoperative feeding with elemental diet. Br Med J 1979; 1: 293-5.

62 Hoover HC, Ryan JA, Anderson EJ, Fischer JE. Nutritional benefits of immediate postoperative jejunal feeding of an elemental diet. Am J Surg 1980; 139: 153-9.

63 Fairfull-Smith RJ, Freeman JB. Immediate postoperative enteral nutrition with a nonelemental diet. J Surg Res 1980; 29: 236-9.

64 Ryan JA, Page CP, Babcock L. Early postoperative jejunal feeding of elemental diet in gastrointestinal surgery. American Surgeon 1981; 47: 393-403.

65 Bastow MD, Rawlings J, Allison SP. Benefits of supplementary tube feeding after fractured neck of femur: a randomized controlled trial. $B r \operatorname{Med} J$ 1983; 287: 1589-92.

66 Dickinson RJ, Ashton MG, Axon ATR, Smith RC, Yeung CK, Hill GL: Controlled trial of intravenous hyperalimentation and total bowel rest as an adjunct to the routine therapy of acute colitis. Gastroenterology 1980; 79: 1199-204.

67 Greenberg GR, Fleming CR, Jeejeebhoy KN, Rosenberg IH, Sales D, Tremaine WJ. Controlled trial of bowel rest and nutritional support in the management of Crohn's disease. Gastroenterology 1985; 88: 1405.

68 Harries AD, Jones LA, Danis V, et al. Controlled trial of supplemented oral nutrition in Crohn's disease. Lancet 1983; 1: 887-90.

69 O’Morain C, Segal AW, Levi AJ. Elemental diet as primary treatment of acute Crohn's disease: a controlled trial. $\mathrm{Br}$ Med $J$ 1984; 288: 1859-61.

70 Abel RM, Beck CH, Abbott WM, Ryan JA, Barnett GO, Fisher JE. Improved survival from acute renal failure after treatment with intravenous essential 1-amino acids and glucose. N Engl J Med 1973; 288: 695-9.

71 Leonard CD, Luke RG, Siegel RR. Parenteral essential amino acids in acute renal failure. Urology 1975; 6: 154-7.

72 Feinstein EI, Blumenkrantz MJ, Healy M, et al. Clinical and metabolic responses to parenteral nutrition in acute renal failure. Medicine 1981; 60: 124-37.

73 Blumenkrantz MJ, Kopple JD, Koffler A, et al. Total parenteral nutrition in the management of acute renal failure. Am J Clin Nutr 1978; 31: 1831-40.

74 Egberts E, Hamster W, Jurgens $P$, et al. Effect of branched chain amino acids on latent portalsystemic encephalopathy. In: Walser M, Williamson JR, eds. Metabolism and clinical implications of branched chain amino and ketoacids. Elsevier: North Holland; 1981: 453-63.

75 Cerra FB, Cheung NK, Fischer JE, et al. A multicenter trial of branched chain enriched amino acid infusion (FO80) in hepatic encephalopathy (HE). Hepatology 1982; 2: 699.

76 Strauss E, Santos WR, Cartapatti da Silva E, et al. A randomized controlled clinical trial for the evaluation of the efficacy of a [sic] enriched branched-chain amino-acid solution compared to neomycin in hepatic encephalopathy. Hepatology 1983; 3: 862 .

77 Fiaccadori F, Chinelli F, Pelosi G, et al. Selective amino acid solutions in hepatic encephalopathy treatment. La Ricerca in Clinica i Laboratorio 1980; 10: 411-22.

78 Rossi-Fanelli F, Riggio O, Cangiano C, et al. Branched-chain amino acids vs. lactulose in the treatment of hepatic coma. Dig Dis Sci 1982; 27: 929-35.

79 Wahren J, Denis J, Desurmont P, et al. Is intravenous administration of branched chain amino acids effective in the treatment of hepatic encephalopathy? A multicentric study. Hepatology 1983; 3: 475-80.

80 Gluud C. Dejgaard A, Hardt F, et al. Copenhagen Coma Group. Preliminary treatment results with balanced amino acid infusion to patients with hepatic encephalopathy. Scan J Gastroenterol 1983; 18,(Suppl 86): 19.

81 Ferenci P, Dragosiis B, Wewalka F. Oral administration of branched chain amino acids (BCAA) and keto acids (BCKA) in patients with liver cirrhosis. In: 
Walser M, Williamson JR, eds. Metabolism and clinical implications of branched chain amino and ketoacids. Elsevier: North Holland, 1981; 507-12.

82 Holm E, Langhans W, Meisinger E, Hiltmann W, Gasteiger P. BCAA-enriched diets for oral treatment of patients with liver cirrhosis: a controlled study of biochemical variables, psychometric performance, and the EEG. JPEN 1981; 5: 354.

83 McGhee A, Henderson JM, Millikan WJ, et al. Comparison of the effects of Hepatic-aid and casein modular diet on encephalopathy, plasma amino acids, and nitrogen balance in cirrhotic patients. Ann Surg 1983; 197: 288-93.

84 Eriksson LS, Persson A, Wahren J. Branched-chain amino acids in the treatment of chronic hepatic encephalopathy. Gut 1982; 23: 801-6.

85 Christie ML, Sack DM, Horst D, Lenger S, Pomposelli J. Enriched branched-chain amino acid formula versus a casein based supplement in the treatment of cirrhosis. JPEN 1984; 8: 91.

86 Horst D, Grace ND, Conn HO, et al. Comparison of dietary protein with an oral, branched chain-enriched amino acid supplement in chronic portal-systemic encephalopathy: a randomized controlled trial. Hepatology 1984; 2: 279-87.

87 Gunn T, Reaman G, Outerbridge EW, Colle E. Peripheral total parenteral nutrition for premature infants with the respiratory distress syndrome: a controlled study. J Pediatr 1978; 92: 608-13.

88 Bryan MH, Wei P, Hamilton JR, Chance GW, Swyer PR. Supplemental intravenous alimentation in low birth weight infants. J Pediatr 1973; 82: 940-4.

89 Brans YW, Summers JE, Dweck HS, Cassady G. Feeding the low birth weight infant: orally or parenterally? Preliminary results of a comparative study. Pediatrics 1974; 54: 15-22.

90 Pildes RS, Ramamurthy RS, Cordero GV, Wong
PWK. Intravenous supplementation of 1-amino acids and dextrose in low birth-weight infants. $J$ Pediatr 1973; 82: $945-50$.

91 Yu VYH, James B, Hendry P, Macmahon RA. Total parenteral nutrition in very low birth-weight infants: a controlled trial. Arch Dis Child 1979; 54: 653-61.

92 Abitbol CL, Feldman DB, Ahmann P, Rudman D. Plasma amino acid patterns during supplemental intravenous nutrition of low-birth-weight infants. J Pediatr 1975; 86: 766-72.

93 Nasrallah SM, Galambos JT. Aminoacid therapy of alcoholic hepatitis. Lancet 1980; ii: 1276-7.

94 Naveau S, Gelleteir G, Poynard T, et al. A randomized clinical trial of total parenteral nutrition (TPN) in jaundiced alcoholic cirrhotic patients. Hepatology 1984; 4: 1043.

95 Diehl AM, Boitnott JK, Herlong HF, et al. Effect of parenteral amino acid supplementation in alcoholic hepatitis. Hepatology 1985; 5: 57-63.

96 Liljedahl S, Larsson J, Schildt B, Vinnars E. Metabolic studies in severe burns. Acta Chir Scand 1982; 148: 393-400.

97 Hyde D, Floch MH. The effect of peripheral nutritional support and nitrogen balance in acute pancreatitis. Gastroenterology 1984; 86: 1119.

98 Hoj L, Osterballe O, Bundgaard A, Weeke B, Weiss M. A double-blind controlled trial of elemental diet in severe, perennial asthma. Allergy 1981; 36: 257-62.

99 Rapp RP, Young B, Twyman D, et al. The favorable effect of early parenteral feeding on survival in head-injured patients. J Neurosurg 1983; 58: 906-12.

100 Young B, Rapp RP, Norton JA, Haack D, Tibbs PA, Bean JR. Early prediction of outcome in head-injured patients. J Neurosurg 1981; 54: 300-3.

101 Koretz R. Nutritional support in acute head injuries. J Neurosurg 1984; 60: 1334-5. 